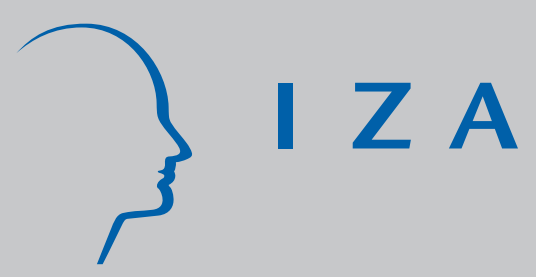

IZA DP No. 337

Overeducation and Skill Endowments

The Role of School Achievement and Vocational Training Quality

Felix Büchel

Matthias Pollmann-Schult

August 2001 


\title{
Overeducation and Skill Endowments The Role of School Achievement and Vocational Training Quality
}

\author{
Felix Büchel \\ Max Planck Institute for Human Development, Berlin \\ and Technical University of Berlin \\ Matthias Pollmann-Schult \\ Max Planck Institute for Human Development, Berlin
}

Discussion Paper No. 337

August 2001

\author{
IZA \\ P.O. Box 7240 \\ D-53072 Bonn \\ Germany \\ Tel.: +49-228-3894-0 \\ Fax: +49-228-3894-210 \\ Email: iza@iza.org
}

This paper can be downloaded without charge at:
http://papers.ssrn.com/abstract=xxxxxx

An index to IZA Discussion Papers is located at: http://www.iza.org/publications/dps/

This Discussion Paper is issued within the framework of IZA's research area The Future of Work. Any opinions expressed here are those of the author(s) and not those of the institute. Research disseminated by IZA may include views on policy, but the institute itself takes no institutional policy positions.

The Institute for the Study of Labor (IZA) in Bonn is a local and virtual international research center and a place of communication between science, politics and business. IZA is an independent, nonprofit limited liability company (Gesellschaft mit beschränkter Haftung) supported by the Deutsche Post AG. The center is associated with the University of Bonn and offers a stimulating research environment through its research networks, research support, and visitors and doctoral programs. IZA engages in (i) original and internationally competitive research in all fields of labor economics, (ii) development of policy concepts, and (iii) dissemination of research results and concepts to the interested public. The current research program deals with (1) mobility and flexibility of labor markets, (2) internationalization of labor markets and European integration, (3) the welfare state and labor markets, (4) labor markets in transition, (5) the future of work, (6) project evaluation and (7) general labor economics.

IZA Discussion Papers often represent preliminary work and are circulated to encourage discussion. Citation of such a paper should account for its provisional character. 


\section{ABSTRACT}

\section{Overeducation and Skill Endowments: The Role of School Achievement and Vocational Training Quality*}

Thurow's job-competition model implies that overeducation is contingent upon the differing skill endowments of employees. As yet, only rudimentary evidence has been furnished to confirm this relationship. In the present paper, we test the theory in a more sophisticated manner, by means of a more differentiated survey of the skill endowments of workers. Our analyses are based on the German Life History Study (GLHS), in which longitudinal biographical data was gathered for the West German cohorts born in 1964 and 1971 up until the year of the survey (1998). These data are analyzed using a trivariate probit model which takes into account the selective acquisition of school qualifications, and the selective choice of vocational training with varying levels of quality.

Our findings confirm that type and grade of school leaving certificate both have a strong effect on the later risk of overeducation. The quality of the vocational training chosen only impacts on the overeducation risk when the strong selectivity effects in certain types of schools and types of vocational training are not taken into account. In line with existing literature, we find that the risk of overeducation decreases with increasing traditional skill measures such as experience, tenure, on-the-job-training, and further education. In sum, our results clearly confirm the capacity of the job-competition model to explain the persistence of overeducation in the labor market.

JEL Codes: $\quad$ I21, J24, J41, J62

Keywords: Overeducation, skills, human capital, school achievement, vocational training, career mobility, intergenerational mobility, selectivity effects

Felix Büchel

Max Planck Institute for Human Development

Lentzeallee 94

D-14195 Berlin

Germany

Tel: $+49-30-82406-427$

Fax: +49-30-8249939

Email: buechel@mpib-berlin.mpg.de

\footnotetext{
*Paper prepared for presentation at the Conference "Market Expansion, Welfare State Retrenchment, and their Impact on Social Stratification", organized by the ISA Research Committee on Social Stratification and Mobility (RC28), 26-28 April 2001, Mannheim, Germany, and at the Research Seminar Series of the Department of Economics at University of Aberdeen, UK, 4 May, 2001.
} 


\section{Introduction}

In recent years, there has been a sharp increase in the number of publications addressing the topic of overeducation (for a recent overview of research findings, see Groot \& Maassen van den Brink, 2000). Workers are considered to be overeducated if the skills they have acquired exceed the skills required to perform their job. There are various explanations for this skill underutilization phenomenon (cf. Hartog, 2000a, b; Büchel, forthcoming a). Nevertheless, the great majority of empirical research is built around the theoretical framework provided by the job-competition model (Thurow, 1975; 1979). ${ }^{1}$ This model is based on the assumption that wages for specific occupations do not react sufficiently to shifts in supply and demand. The wage rigidity observed in many empirical studies lends strong support to this assumption. As a result of this rigidity, the wage competition expected in neo-classical economics is replaced by job competition (Borghans \& de Grip, 2000).

The job-competition model entails a matching process in which two queues have to be brought into line: the job queue and the person queue. Jobs in the job queue are sorted according to the skills they require. Individuals competing for these jobs also form a queue, their relative position being determined by the qualifications they have acquired. For employers, these qualifications are an indication of the costs of training the applicants in the skills required to perform a specific job. The higher an individual's position in the person queue, the less the expected cost of training, and the more likely he or she will be given a job at the upper end of the job queue: "Instead of competing against each other on the basis of wages, individuals compete for jobs on the basis of background characteristics" (Muysken \& ter Weel, 2000:120). Traditionally, this set of background characteristics is understood to be an array of various components of productive skills forming a human capital stock $^{2}$ (Schultz, 1961; Becker, 1964). ${ }^{3}$ The most important components apart from schooling, upon which research interest is focused, include work experience, job (or firm) tenure, and on-the-job training. The individual elements in an array may well occur as substitutes for each other: what matters is the total amount of skills. Those with fewer skill endowments are allocated a

\footnotetext{
$1 \quad$ The most important competing theory is the career mobility theory advanced by Sicherman \& Galor (1990). For an explicit test with respect to overeducation, see Sicherman (1991), but see also Büchel \& Mertens (2000) for a critical review.

In this paper, we use the term "(productive) skills" rather than that of "human capital" to be in line with Thurow's terminology. We believe, however, in the synonymous character of both expressions. By developing an integrated approach, Muysken \& ter Weel (2000) have been able to show - in the express context of overeducation - that this approach can still be vindicated if the various ele ments of the array
} 
less favorable position in the person queue than individuals with the same formal qualifications but better "supplementary" qualifications. As a result of such bumping-down or crowding-out effects, these individuals are at risk of skill underutilization or even unemployment. To summarize, in Thurow's theoretical framework, overeducation can be seen as resulting from a lack of skill endowments: "Overeducation may be a compensation for a lack of other relevant productive skills necessary for the job" (Groot \& Maassen van den Brink, 2000:157).

Thurow's job-competition model derives its lasting attractiveness from the fact that it is both simple and intuitively convincing. However -and this may come as a surprise in view of the far-reaching influence that the theory has exerted on skill mismatch research- there is no sophisticated empirical evidence for the explanatory power of the job-competition model with respect to overeducation. Some authors such as Sloane et al. (1999) even take the view that the model is unable to explain the persistence of overeducation. They argue that the rewards observed for the surplus education component possessed by overeducated workers (found by Duncan \& Hoffman, 1981, among many others) are incompatible with the essential theoretical part of the job-competition model, which predicts that only job requirements, and not the skills of job holders, determine wages. If, however, job requirement levels can only be roughly measured in surveys, there will be much heterogeneity of job quality within the particular categories of the measurement scale. If then -consistent with the expectations of the job-competition model- overeducated workers are matched to the more demanding jobs within a particular job requirement level, they can -again in line with the model- be expected to earn higher wages than the average for those categorized to the same job requirement level. This would explain the empirically observed wage premiums for overeducated workers. To summarize, we believe that the existence of these wage premiums can be attributed to imprecise measurements of job demand levels rather than to a failure of Thurow's jobcompetition model.

In line with expectations of the model, empirical studies often establish that the risk of skill underutilization decreases with increasing work experience, tenure, and participation in onthe-job training (for an overview, see Hartog 2000b; Groot \& Maassen van den Brink, 2000; Borghans \& de Grip, 2000). However, it seems to be problematic to rely only on these rather crude measurements of productive skills. Some authors, e. g., pointed to the fact that other 
factors such as ability must also be seen as an independent and substitutable component of skills (Hartog, 2000a:16; Muysken \& ter Weel, 2000:111). ${ }^{4}$

With the present study, we intend to intensify research efforts to find a more precise measure of the skill endowments of overeducated and correctly allocated workers. The study focuses on the question - explicitly raised by Borghans \& de Grip (2000:19) - of whether, within a group of workers with comparable formal qualifications, it is possible to isolate deficits in the remaining components of skills which put specific individuals at risk of skill underutilization. In other words, we address the question of whether the "other relevant productive skills necessary for the job" mentioned by Groot \& Maassen van den Brink can be more clearly determined by empirical means. In addition to the traditional components of skills as those treated in human capital theory (experience, tenure, and on-the-job training, as well as further education leading to additional degrees) we also control for the level of schooling in the parental home, which is taken as a proxy for specific skill components such as social skills and specific, later employable knowledge that cannot be tapped by school achievement measures. General school education is assessed in terms of the type and grade of school leaving certificate. Furthermore, we assess the quality of the skills acquired in vocational education by taking the labor market prospects of workers with this kind of training as a proxy. $^{5}$

Apart from this first objective - to test the hypothesis of whether, within groups of individuals with comparable schooling, those with fewer "supplementary" skill endowments are assigned to bwer positions in the person queue, and thus run a higher risk of skill underutilization - we also pursue a second objective with a more methodological slant. For Germany, it has been

Weiss, 1995).

$4 \quad$ In the field of wage research, this postulate is underpinned by a study conducted by Vella \& Gregory (1996), which showed that overachievers in school - i.e., those with higher levels of education than predicted by their socio-economic background - earn below-average wages compared with others with the same amount of education, and vice versa. Similarly, Leuven et al. (2000) showed that analyses of wage inequality which measure skills in terms of schooling and experience only are markedly inferior to operationalizations that use more differentiated skill measures, including ability measured in terms of individual literacy. In comparison, efforts to take ability into account in the field of overeducation research are still in their elementary stages. Hartog \& Jonker (1998) attempted to measure ability using an IQ test. However - for whatever reasons - there were barely any overeducated workers in the cohort data set on which their analysis was based. Hence, the authors are only able to analyze the effect of IQ on the probability of working in a job for which one is undereducated. The expected positive relationship between IQ and the probability of undereducation was only found for the group of 43-year-old employees, and even here the relationship was weak; no significant effect at all was observed for the group of 53-year-olds. (Surprisingly, the effect of IQ on variants of dependent variables that are highly similar in terms of content-deficit in capabilities; deficit in schooling- differs greatly: one effect is negative, the other positive.) 
shown that those who complete poor-quality vocational training schemes run a higher risk of working in jobs for which they are overqualified than their peers (Büchel \& Neubäumer 2001). One important reason for this phenomenon is that those sectors that offer jobs with poor working conditions tend to train more apprentices than will later be required as skilled workers. By taking this course of action, which can be justified by branch-specific differences in production and transaction costs (Neubäumer 1999), the firms compensate for the aboveaverage rates of anticipated dropout (migration of workers to other sectors of the economy). Those trained in "problem" occupations run a higher risk of unemployment and skill underutilization. It is also undisputed that lower-achieving school leavers are overrepresented among those taking up apprenticeships in these risk sectors and/or in risk occupations. ${ }^{6}$ This means that if, in an econometric model intended to identify the determinants of overeducated work (vs. correctly allocated work), vocational training and school achievement are controlled for in conventional form, results are likely to be severely biased by covert selectivity effects.

Therefore, before we embark on the overeducation analysis constituting the focal point of the present study, the determinants of (a) the quality of the school leaving certificate and (b) the quality of the vocational training will be identified in two preliminary steps. We will then link the error terms of the three models (analysis of the fit of acquired and required skills as the main step, analysis of the quality of the school leaving certificate and analysis of the quality of the vocational training as preliminary steps) in a simultaneous trivariate probit model in order to control for selectivity effects which could potentially bias the results of our main analysis.

\section{Data and Methods}

\subsection{Data and Case Selection}

Our empirical analyses are based on a survey conducted by our own research center: the German Life History Study (GLHS). The data set is based on retrospective surveys, conducted at different points in time, of the life-course data of selected birth cohorts, with a particular focus on educational and occupational careers (see, for example, Brückner \& Mayer

\footnotetext{
5 This variable is operationalized by the official rate of unemployment for the specific occupation at the time the respondent embarked on his or her vocational training.
} 
1998). The present study is based on data collected in 1998 from the West German cohorts born in 1964 and $1971 .^{7}$ This database is eminently suitable for our research questions inasmuch as it is the only database - in Germany and probably the world - to provide detailed information not only on the fit of acquired and required education, but also on the social background, school achievement, chosen vocational training, and early occupational careers of the respondents.

The addresses of the men and women in our stratified sample were randomly drawn from the official registers of 100 West German communities which, in geographic and demographic terms, can be regarded as representative of the resident population of West Germany. A total of 2,911 participants completed the entire survey, corresponding to a coverage rate of $66 \%$. A nonresponse study did not reveal any noticeable differences between participants and nonparticipants which might indicate systematic drop out (see the methodological report of the survey institute infas [1999] for details). The German Life History Study is characterized by the high levels of data quality it aims to achieve. A team of student workers checks the data gathered for every single biography in terms of completeness and, particularly, internal consistency. This process takes approximately one year to complete, and was still in progress at the time of writing. The present study is based on a version of the data released on 1 April, $2000 .^{8}$

The primary objective of the study is to tap differing skill endowments, with the emphasis on "unconventional" components of productive skills. As these components can be expected to correlate highly with formal qualifications, we limit our analysis to a group of workers which is largely homogeneous in terms of formal education. Specifically, we focus on those workers having a vocational, i. e. a non-academic degree ${ }^{9}$. Individuals with more than one post-school qualification in the vocational area - e.g., those who completed two vocational training, or earned an additional technical college (Fachschule) or master craftsmen degree remain in the

6 The job-competition model can also be used as a theoretical construct to describe processes of selection and allocation in school leavers' competition for vocational training in the vocational training system.

$7 \quad$ Note requested by the project management: "The biographical data used here were collected as part of a research project entitled 'Education, Training and Occupational Careers of the 1964 and 1971 Birth Cohorts in West Germany' (MPI/IAB). This project was conducted by the Max Planck Institute for Human Development, Berlin (Center for Sociology and the Study of the Life Course) in cooperation with the Institute for Employment Research of the Federal Labor Office (IAB), Nuremberg, which received financial support from the European Social Fund (ESF) for this purpose."

$8 \quad$ Our empirical results should therefore be viewed as preliminary.

9 The vast majority of these people hold an apprenticeship degree; a minority holds other vocational degrees received at Berufsfachschulen (full time vocational schools), schools of public health, or schools for civil servants. 
sample, but not those who followed up their vocational training with a university degree. Those workers concurrently undergoing full-time education were excluded as well. ${ }^{10}$ Our master sample thus consists of 1428 participants from the 1964 and 1971 birth cohorts who had completed a vocational training and were in regular employment at the time of the survey (1998). Forty of these respondents gave implausible data for the overeducation variable (see below for details of coding) and other required data were missing for another 114 respondents. These respondents were eliminated from the sample, thus leaving us with a sample of 1274 for our analyses.

\subsection{Models}

Our primary objective in this study is to investigate the effects of various components of skills on the risk of working in a job for which one is overeducated. To this end, we distinguish four groups of skill variables: i) conventional variables (experience, tenure, on-the-job training), including further education; ii) quality of vocational training; iii) school achievement before starting the vocational training; iv) parental background. Further details on the construction of the variables and additional control variables are given in section 2.3.

The influence of these four groups of skill variables on the probability of overeducation was calculated using two types of model. First, we run a conventional probit model (Greene, 2000:814f.), referred to here as Model Ia. We then take into account the empirically established fact that the sequential accumulation of the "school achievement" and "quality of vocational training" components of skills - entered in our model as independent variables - is largely selective, and that it can be assumed that in this process of selection, the magnitude of these components of skills is determined by the same covert factors as later determine the risk of overeducation. In order to control for this effect, we run a three-step simultaneous model (Model II) in the form of a multivariate probit model (Greene, 2000:856f.) with the binary dependent variables: i) overeducated work (vs. correctly allocated); ii) completion of vocational training with poor employment prospects (vs. completion of "low-risk" vocational training); iii) lower-level school leaving certificate (vs. higher-level certificate) ${ }^{11}$. Our main

\footnotetext{
10 An additional condition for inclusion in the analyses was that the respondent attended a West German school immediately before embarking upon his or her vocational training. This ensures that the school achievement measured in the present study pertains to a West German school leaving certificate.

$11 \quad$ For our definitions of a vocational training with poor career prospects and of lower-level school leaving certificates, see section 2.3.3.
} 
interest here is in the results of the first step of this "trivariate" probit model, which we expect to provide more consistent estimates than the single equation model Ia. ${ }^{12}$

\subsection{Variables}

\subsubsection{Overeducation variable}

There are several ways of measuring the fit of acquired and required schooling among workers. Two main approaches can be distinguished, however: the objective and the subjective approach. In the objective approach, every occupation is assigned a particular joblevel requirement, which is then compared with the actual education level of the respondent. On the basis of this information, it is possible to determine whether each individual worker has surplus, adequate, or deficit education for his or her job. Another variant of the objective approach is the realized-matches approach, in which the actual distribution of qualifications within a given occupation is taken as an indicator for the qualifications required. If the qualification attained by a given respondent is markedly above or below the "standard" educational level within the particular occupation (e.g., more than one standard deviation above the mean or the median), a skill mismatch is diagnosed.

The subjective approach is based on self-assessment. The workers themselves report which qualifications are usually required to perform their job. The skill mismatch variable is then determined by comparing this information with the actual formal educational qualifications of the worker in question (for a detailed description of competing forms of measurement, see Hartog, 2000b; Borghans \& de Grip, 2000; Büchel, forthcoming a). The subjective approach is predominant in more recent empirical studies; it is assumed that the worker in question is in the best position to judge which qualifications are actually necessary for the job he or she performs: "This [subjective approach] has the advantage of obtaining information from the source closest to the actual job situation, taking account of all specific circumstances." (Hartog \& Oosterbeek, 1988:186). Methodological analyses indicate that results are relatively robust with respect to the form of measurement chosen (Hartog, 2000a).

\footnotetext{
12 For comparative purposes, we also report the results of the conventional single-equation probit estimates of the first two steps of Model II (Models Ib, Ic).
} 
In the present study, an elaborated form of the subjective approach was used. After detailed information had been gathered on the job performed, the workers in our sample were asked the following question: "What sort of training is usually necessary to perform this job?" Respondents selected one of the following categories: i) "no completed vocational training"; ii) " completed college/university degree"; iii) " completed vocational training or comparable training/courses". Answer iii) is tailored to the population of workers with a completed vocational training (see section 2.1) focused on in the present study, and thus indicates correct allocation. Answer i) indicates skill underutilization and thus overeducation. In line with a widely used procedure, we only wanted to construct a dummy variable with the attributes "overeducated: yes or no." Some very few undereducated workers (answer ii) were therefore assigned to the "not overeducated" category.

In an additional step, we use the strategy suggested by Büchel and Weißhuhn (1998:58f.) ${ }^{13}$ to increase the validity of this categorization, and verify this first categorization by means of a third variable: occupational position. This results in the generation of two further categories: "implausible combinations" (of acquired education, required education, and occupational position) and a "gray area" (Hecker, 1992), in which the combined data from the three original variables do not allow a respondent to be conclusively classified as either "overeducated" or "not overeducated" (degree of mismatch not clearly determinable), although the combination is not essentially implausible. Individuals providing implausible combinations were excluded from the analyses $(2.8 \%) .{ }^{14}$ For those respondents classified as belonging to the gray area (5.7\%), we refer back to the occupation as an additional validation variable. Of the 83 cases in question, the original categorization of 44 respondents was retained after checking their occupational position; the remaining 39 respondents were recategorized. The decisive factor in this recategorization was whether or not the job performed actually requires vocational training. ${ }^{15}$ As a result $9.2 \%$ of the workers in our sample were categorized as being overeducated. This overeducation rate is comparable to that calculated

\footnotetext{
13 For an English-language text, see Büchel (forthcoming a).

14 Example: A respondent (with a vocational training, by case selection) works in an unskilled blue-collar job, but states that a college or university degree is required to perform his or her job. This respondent is recategorized from "not overeducated" to "implausible combination" and excluded from our analyses.

15 Example: A respondent (with a vocational training, by case selection) works in an unskilled blue-collar job, but states that a vocational qualification is required to perform his job. The information on his occupation reveals that he works as a docker. This respondent is re-categorized from "not overeducated" to "overeducated".
} 
with data from the German Socio-Economic Panel (GSOEP); the results were thus regarded as satisfactory in terms of validity. ${ }^{16}$

\subsubsection{Covariates used in Model Ia}

The following covariates were used in model Ia:

- birth cohort (1964 vs. 1971);

- gender;

- child(ren) aged below seven years in the household: yes/no (interaction term, women only); ${ }^{17}$

- father's schooling (in years);

- nationality of parents: both foreigners (yes/no), ${ }^{18}$

- type of school leaving certificate acquired at the end of general education (i.e., before starting the vocational training); dummies:

- lower leaving certificate (einfacher Hauptschulabschluss) or no certificate at all (lowest level), earned by lower secondary school (Hauptschule) leavers,

- lower intermediate leaving certificate (qualifizierter Hauptschulabschluss), earned by lower secondary school (Hauptschule) graduates,

- upper intermediate leaving certificate (Realschulabschluss), earned by intermediate secondary school (Realschule) graduates,

\footnotetext{
16 The rate of overeducation in the GSOEP sample is $10.8 \%$ (own calculations; not shown in table). Because of the limited number of respondents per cohort in the SOEP data, the data for five adjacent cohorts were pooled (1962-1966 and 1969-1973 respectively).

17 In Germany, children usually start school at the age of six. For a sample as young as ours, it would be pointless to distinguish those respondents with older children, e.g., children up to 16 years.

18 In pretests, this variable emerged to have more explanatory power than the nationality of the respondent. Some of the non-native respondents adopted German citizenship during the period of observation. With respect to central social characteristics, however, these individuals have more in common with the nonnative population than with indigenous Germans.
} 
- upper leaving certificate (Abitur or Fachabitur; highest level), earned by specialized or non-specialized upper secondary school (Fachgymnasium or Gymnasium) graduates;

- grade of school leaving certificate (interaction term by school type) on a scale ranging from 1 = "very good" to 6 = "fail"):

- grade of lower leaving certificate (or no leaving certificate at all),

- grade of lower intermediate leaving certificate,

- grade of upper intermediate leaving certificate,

- grade of upper leaving certificate;

- quality of the vocational training, operationalized by its employment prospects. The rate of unemployment in the specific occupation at the time the respondent embarked upon the vocational training serves as an indicator for career prospects here. ${ }^{19}$ Dummy: vocational training with "normal" vs. poor employment prospects ("unproblematic" occupation: yes/no); ${ }^{20}$

- eventually additionally acquired vocational degrees in the period from the end of the vocational training to the time of the survey in 1998. Two dummies: i) Additionaly acquired vocational degree of same qualification level as the first one (e. g. second apprenticeship in another occupation); ii) Additionaly acquired vocational degree of higher qualification level (mainly degrees from specialized technical colleges, Fachschulen);

- work experience (in years) in the period from the end of the vocational training to the time of the survey in 1998;

- firm tenure at time of the survey in 1998. Dummy: "longer than 6 months: yes or no."; ${ }^{21}$

\footnotetext{
19 For occupations with more than fifty respondents per cohort in our sample: rate of unemployment in the occupation (3-figure occupational code); for occupations with fewer respondents: rate of unemployment in the occupational group (2-figure code). Source: Federal Labor Office.

20 Respondents' employment prospects are classified as "poor" if they completed their vocational training in an occupation located in the upper decile of the distribution of occupation-specific unemployment rates. The differing economic situation at the time each of the birth cohorts began their vocational training needs to be taken into account here (1964 cohort: occupation with an unemployment rate of $>4.8 \%$ in $1980 ; 1971$ cohort: occupation with an unemployment rate of $>11.0 \%$ in 1987).

21 This rather atypical operationalization is necessary because, for our younger respondents, the conventional measurement of firm tenure in years correlates highly with work experience. This causes problems
} 
- participation in on-the-job training, operationalized by the number of training measures.

\subsubsection{Variables used in Models Ib and Ic}

\section{Dependent Variables}

In model Ib, we determine the factors influencing the probability of embarking upon an "unproblematic" (vs. high-risk) vocational training; see section 2.3.2. for details of the operationalization.

In model Ic, we determine the factors influencing the probability of leaving school with at least an upper intermediate leaving certificate (vs. a lower intermediate leaving or less).

\section{Covariates}

In model Ib, the following are entered as covariates: birth cohort, gender, father's schooling (in years), nationality of parents, type of school leaving certificate, and grade of school leaving certificate by type (see section 2.3.2 for details of the operationalization).

In model Ic, the following are entered as covariates: birth cohort, gender, father's schooling (in years), nationality of parents (see section 2.3.2 for details of the operationalization). 


\section{Empirical Results}

\subsection{Descriptive Results}

As shown in Table 1, the risk of overeducation is highly dependent on some components of the social background and skills of the respondents, with the latter group of variables playing more pronounced role than the former.

*** Please insert Table 1 about here $* * *$

The proportion of overeducated workers is somewhat higher in the 1964 cohort than in the 1971 cohort. This difference may be explained by the markedly different labor market conditions prevailing at the time each of the cohorts entered the labor market: the 1964 cohort was confronted with a downturn on the labor market, the 1971 cohort with an economic upturn. $^{22}$

We found no gender-specific differences in the risk of working overeducated. ${ }^{23}$ Women with preschool children, however, are much more likely to be overqualified for their jobs.

Respondents whose parents' have only a low level of schooling are over-represented among the group of overeducated workers. This is remarkable considering that, by case selection, all respondents have attained the same level of formal education - a vocational training. Similarly, respondents whose parents do not have German citizenship are more likely than their peers to have more education than their jobs require; this effect is not significant, however. $^{24}$

\footnotetext{
$22 \quad$ Furthermore, Büchel \& Weißhuhn (1998:44f.) have shown that the risk of overeducation among individuals with intermediate-level formal qualifications increases with age. Neubäumer (1999) attributes this effect to the increasing health-related problems that blue-collar workers, in particular, experience with age, and to general skill obsolescence effects. The latter effect is especially relevant for mothers re-entering the labor market after periods of childcare.

23 This finding contradicts previous results reported in the overeducation literature, which tend to identify women as being at a much higher risk of overeducation. This can presumably be attributed to the particular case selection in the present study, and to the fact that we focus on younger workers, and exclude those in irregular work from the analyses. In West Germany, it is primarily women with low- and mid-level qualifications who do such irregular work, and a disproportionate share of overeducated workers are employed in this sector. $24 \quad$ It may be perceived as surprising that this effect is not significant, as German studies usually find non-
} German status to have strong negative effects on all kinds of educational outcomes. It should be noted, however, 
We identified a highly significant relationship between the type of school leaving certificate and the risk of skill underutilization later on. More than $15 \%$ of those who leave school with only a lower leaving or even no leaving certificate, but are nonetheless able to find a suitable vocational training and complete their vocational training successfully, later work in jobs for which they are overeducated. A somewhat lower risk of overeducation could be observed for those with lower intermediate leaving certificate. The risk of overeducation decreases markedly with a higher-level school leaving certificate, however. The rate of overeducation among intermediate secondary school graduates is only half as high as that among lower secondary school leavers, and less than $4 \%$ of those who leave school with an upper leaving certificate and atypically opt not to go on to higher education, but to take up a vocational training, later have too much schooling for their job. This constitutes a first important finding of the present study: regardless of the quality of the later vocational training, a higher-level school leaving certificate is an important component of skills, and affords effective protection against the risk of overeducation.

We now consider school achievement in a rather more differentiated manner than in terms of the type of school leaving certificate alone, and study the grades attained in this qualification as an additional indicator for school achievement. A notable result emerges here, namely that the lower leaving certificate and the lower intermediate leaving certificate are no longer of similar value. Among respondents who leave school with no qualifications at all or with only a lower leaving certificate, the grade of the school leaving certificate does not seem to affect the risk of overeducation later in their occupational career. It can be assumed that this certificate represents such a low level of qualification - whether in terms of the skills actually acquired or the signaling effects vis-à-vis employers - that a qualitative differentiation makes no difference to the risk of skill mismatch. For school leavers with at least a lower intermediate leaving certificate, however, the situation is quite different. If these students attain a good grade in this qualification (and go on to successfully complete a vocational training), there is a marked reduction in the risk of skill underutilization. A significant relationship between the grade of the school leaving certificate and the risk of later overeducation can also be observed for intermediate secondary school graduates. Only very few of the respondents with a good upper intermediate leaving certificate were found to be overeducated, but a bad upper intermediate leaving certificate proved to put the respondents at 
a higher risk of overeducation than a good lower intermediate leaving certificate. Finally, for upper secondary graduates, no significant relationship was found between the grade of the school leaving certificate and the risk of skill underutilization. The relationship between the grade of the school leaving certificate and the likelihood of skill mismatch later in life constitutes a second important result of the present study. Indeed, it is not the type of school leaving certificate that is the determining factor here; where intermediate-level qualifications are concerned, it is the grade of the school leaving certificate that is decisive.

Hardly surprising, the quality of the chosen vocational training is of great relevance for the later risk to work overeducated. About every sixth of those who completed a vocational training in an occupation with poor employment prospects later works in a job for which he or she is overqualified. Among those who chose a low-risk vocational training, this figure drops to less than half. This constitutes the third important finding of our analysis. Because the attribute "poor employment prospects" was operationalized by the rate of unemployment in the specific occupation, this observation also leads to the noteworthy conclusion that unemployment and overeducation are not merely typologically related labor market statuses (Büchel, forthcoming a), but that there is a positive relationship between the occupationspecific risk of unemployment and overeducation.

Those people acquiring multiple vocational degrees of the same qualification level cannot reduce their overeducation risk significantly. The contrary is the case for those who acquire an additional vocational degree on a higher qualification level. This finding is in line with the fact that the risk of working overeducated is negatively correlated with the level of formal qualification of workers (Büchel \& Weißhuhn, 1998).

There is a highly significant correlation between the likelihood of overeducation and low levels of firm tenure and on-the-job training. This is not the case with work experience. The multivariate analysis will indicate that this somewhat unexpected descriptive result is caused by cohort effects. When controlling for this effect, longer work experience results, as expected, in a lower risk to work overeducated.

To summarize, our descriptive analysis confirms that there is a strong relationship between skill endowments and the risk of skill underutilization. Moreover, as predicted by the job- 
competition model, the skill components "school achievement" and "quality of vocational training", which have thus far been largely neglected in the overeducation literature, proved to play a key role.

\subsection{Results of the Econometric Models}

\subsubsection{Results of the Binary Probit Model on Overeducation}

In a first step, we use the standard procedure of a binary probit model to determine the factors influencing the risk of overeducation. In sum, the results displayed in Table 2 (left-hand column: Model Ia) show that the few significant differences in the group of variables reflecting the respondents' social background that were identified in the descriptive analysis and that were already relatively weak - decrease further in magnitude. In contrast, even when controlling for a variety of effects, the differences in skill endowments identified in the descriptive analysis remain largely stable.

*** Please insert Table 2 about here ***

The lower risk of overeducation of the younger birth cohort, compared with the older one, holds when controlling for other variables. As in the descriptive analysis, gender and parents' nationality have no significant effects on the risk of overeducation. However, when controlling for other important properties, particularly skill endowments, the higher risk of skill underutilization which emerged for women with preschool children in the descriptive analysis is no longer found in the binary probit model. Similarly, whereas the descriptive analysis identified respondents whose parents' had only a low level of schooling as being at a higher risk of overeducation, this variable does not prove to be a risk factor in the binary probit model.

Much stronger effects are to be found among the group of skill variables. With respect to the two types of school leaving certificate found to be associated with similar risks of overeducation in the descriptive analysis, a differentiation now emerges. Relative to 
intermediate secondary school graduates, students with a lower leaving certificate or no qualifications at all are at a significantly higher risk of later skill underutilization. In contrast, a negative effect of a lower intermediate leaving certificate cannot be observed any longer. At the same time, the respondents with a higher leaving certificate are not at significantly less risk of overeducation than their peers with an upper intermediate leaving certificate.

The effects of the grade of school leaving certificate are also worthy of note. For respondents with a lower leaving certificate or no qualifications at all, who - as shown above - are much more likely to be overeducated, the grade achieved does not seem to make any difference to the risk of skill mismatch. In other words, this type of formal qualification is so basic that higher levels of achievement in this lowest sector of the qualification distribution are no better rewarded. This is not the case for the lower and upper intermediate leaving certificates certificates typical of those later taking up a vocational training -, however. Students who achieve a good grade in these qualifications can significantly lower their risk of skill underutilization. For those leaving school with a higher leaving certificate, the grade of the leaving certificate again seems to have no identifiable effect on the risk of overeducation.

Those who opted for a vocational training with poor career prospects are at a significantly higher risk of overeducation. However, in contrast to the findings of the descriptive analysis, this effect is surprisingly weak.

Consistent with the descriptive findings, an additionally acquired vocational degree which is on the same qualification level as the one initially acquired does not lower the risk of overeducation. The additional skill investment has no effect. The contrary is the case if a further degree on a higher level can be reached. This strategy reduces the overeducation risk.

With respect to the classic forms of skill measures, it was shown that even when controlling for other properties, the effects identified in previous overeducation studies continue to emerge: longer periods of work experience and firm tenure reduce the risk of overeducation, as does increased participation in on-the-job training.

The results reported in this section can be summarized by concluding that the findings of the descriptive analysis - that increased skill endowments reduce the risk of overeducation continue to hold or even become more pregnant when controlling for other important 
properties such as the social background. This confirms the predictions of the theoretical approach tested in the present paper, i. e. the job-competition model.

\subsubsection{Results of the Overeducation Equation of the Multivariate Probit Model}

When the risk of overeducation is not estimated in isolation, as was the case in Model Ia, but at the same time as the risk of having acquired only a lower-level school leaving certificate and/or entered a vocational training with poor career prospects (see section 2.2 for the reasoning behind this), the results of the overeducation equation remain largely stable (see Table 2, right-hand column: model II).

Birth cohort has still a (weakened) significant impact on the risk of overeducation; gender, pre-school children in the household, parents' schooling, and nationality have not.

Respondents with no or only a lower leaving certificate are much more likely to be overeducated than the reference group of upper intermediate leaving certificate holders; however, the effect loses strongly in significance. Where intermediate secondary graduates are concerned, there is no decrease in the strong negative effect of attaining a low grade in the leaving certificate. This holding effect is most remarkable when taking into account that applying a multivariate model in general shows much lower significance effects than a single equation model.

It is worth noting that - in contrast to the results of Model Ia - taking up a vocational training with poor career prospects no longer has a significant negative effect on the risk of skill underutilization. The selective access to qualitatively different school leaving certificates and later to qualitatively different vocational training schemes - both of which were controlled for in model II - evidently has a neutralizing effect here. A vocational training with poor career prospects is not an overeducation risk in itself, rather it "only" becomes a risk as the outcome of a process of selection which is sequentially determined by the factors "educational background," "school achievement," and "choice of vocational training." This weakening of the effect occurs even though the correlations of the error terms in the trivariate probit model proved to be not significant. 
In contrast, the positive effects of higher values in the classical skill components of work experience, firm tenure, and on-the-job training are retained, though he first two factors reach only a reduced level of significance. No change is observed with respect to the positive impact of an additionally acquired higher vocational degree - which stands for an important component of skills, related to that covering on-the-job training, as well - on the risk of overeducation.

\subsubsection{Results of the Quality of Vocational Training and Quality of School Leaving Certificate Equations}

The results of the first two equations in the trivariate probit model are of only secondary interest in the present context of investigation, and will thus only be reported in summary form. Results are documented in Appendix Tables A1 and A2 (right-hand columns). For documentary purposes, however, the results of a corresponding single equation model are reported as well (Models Ib, Ic in left-hand columns of Appendix Tables A1 and A2).

\section{Vocational training equation}

When focusing on the results of the single equation probit model (left-hand column of Appendix Table A1), we can observe the well-known fact that young women are much more likely than young men to opt for a vocational training with poor employment prospects. This is striking in view of the fact that the former are more likely to leave school with a higherlevel qualification than the latter (see below). In empirical literate well-established as well is the finding that those with poor schooling qualification, i. e. no or a lower leaving certificate, are selected above-average to training occupations with poor employment prospects. The same is true for those people who earn an upper intermediate leaving certificate, but only with poor grades.

When controlling for strong selectivity effects already at time of selection into different type of schools (see below), however, we can observe a drastic reduction of significance in all discussed effects. Only the (important) impact of poor grades among those with upper intermediate leaving certificate holds on a relatively weak $10 \%$ significance level. This means 
that the selection into vocational training of different quality is strongly driven by unobserved effects already determining the selection to various types of schools, which seems to be plausible.

\section{School leaving certificate equation}

The results of both models (Ic, II in Appendix Table A2) replicate well-known findings from the overeducation literature. The younger birth cohort has a significant higher probability of leaving school with a higher-level qualification, which reflects the secular trend to higher education in Germany. Young women typically leave school with better qualifications than young men. Respondents from families with lower levels of schooling are significantly less likely to achieve a higher-level leaving certificate than their peers. After controlling for the parents' schooling, the parents' nationality plays a minor role. To conclude, it should be noted that the results of this step in the analysis, investigating a point in time that occurs earliest in the life course of all analyzed situations, emerge to be the most robust with respect to the procedure chosen for the analysis.

\section{Summary and Conclusions}

The job-competition model (Thurow, 1975; 1979) predicts that the (visible) skills of job applicants will determine their relative position in the labor queue, and thus their risk of overeducation. This theory has not yet been adequately tested within the framework of overeducation research. Instead, the negative correlations generally calculated between the classic skill components - schooling, work experience, firm (or job) tenure, and participation in on-the job training - and the risk of overeducation were regarded as providing sufficient evidence for the explanatory power of this theory. This seems to be problematic because the mentioned variables play a key role in other explaining theories as well. As a consequence, the "well-functioning" of these variables cannot be taken as a satisfying confirmation of Thurow's model. In the present investigation, we attempted to measure the skill endowments of our respondents in a more differentiated manner, and analyzed the effects of the various skill components on the risk of overeducation. 
The present study is based on data from the German Life History Study (GLHS), collected by our own research center in 1998. These data provide information on the West German cohorts born in 1964 and 1971. After a conventional binary probit model, we run a multivariate probit model with three equations, taking account of the selectivity effects which restrict access to higher-level school leaving certificates and vocational trainings with good labor market prospects.

In order to explore the effects of the various skill components in more detail, we keep the initial level of qualification of the workers in our analyses constant by case selection, and restrict our analyses to individuals who have completed a vocational training - the most common form of qualification in Germany. We measure the school achievement before entering the vocational training system of these respondents in terms of the type of school leaving certificate acquired on the one hand, and the grade achieved within this level on the other. The quality of the chosen vocational training is then measured in terms of the unemployment rate in the specific occupation. Finally, genetic or socialization-related skill components are measured in terms of the educational level of the parental home. We also control for the classic skill components (work experience, firm tenure, and participation in onthe job training) and for the eventual acquisition of a further vocational degree.

Our results show that, within a group of respondents with similar formal qualifications, skill endowments are markedly more important in determining the risk of overeducation than measures of socio-economic status. School achievement plays a key role here. Vocational degree holders who left school with a lower school leaving certificate or no qualifications at all are much more likely than their better educated peers to have too much schooling for their job. This effect only reaches a low level of significance, however, when controlling for selective access to this type of certificate. Even attaining a higher grade in the school leaving certificate does not decrease the risk of skill underutilization for those with this lowest level of formal education. In contrast, with respect to the lower and the upper intermediate school leaving certificates - the qualification typically achieved by those taking up a vocational training - a strong relationship emerges between the grade of the school leaving certificate and the risk of overqualification. Similar to those with lowest school leaving certificates, for those respondents with the highest level of school leaving certificate the grade of the school leaving certificate has no significant effect on the later mismatch risk. 
This clear pattern of results indicates that on the edges of the distribution of school achievement, later risks of skill underutilization are determined by the type of school leaving certificate alone, whereas in the middle of the distribution, the grade of the leaving certificate is also of great relevance. As far as educational policy is concerned, this implies that lower secondary school graduates who aspire only to a lower leaving certificate have little chance of affecting their later career prospects by their own individual efforts if these efforts result only in higher grades, and not in a lower intermediate certificate. In contrast, the chance of acquiring a lower intermediate leaving certificate, which is available to students in some of the German Bundesländer, proves to be of great value: the grade achieved in this type of leaving certificate emerges to have a remarkable differential effect on the risk of overeducation. Intermediate secondary school graduates as well have a powerful incentive to secure themselves a decisive advantage over their lower-achieving peers on the labor market by attaining higher grades in their leaving certificate. Students who attain a higher leaving certificate - more specifically, those who aspire only to vocational training and opt out of a degree course - have already reached the pinnacle of creditable achievement in the form of their certificate. In other words, and in the context of overeducation at least, any effort invested by these students to achieve a better grade in their leaving certificate has no measurable effect on their chances in the middle segment of the labor market which is reserved for those with a completed vocational training.

The effect of the quality of the vocational training on the risk of overeducation proved to be sensitive to the type of modeling procedure chosen. In a conventional econometric model, choosing a vocational training with poor labor market prospects emerged to be a significant risk factor. However, when controlling for the fact that allocation to a high-risk occupation is highly dependent on the level of school education acquired previously (and that the level of school education is in turn highly dependent on, for example, the parents' schooling), this effect is weakened, and no longer reaches the requested level of significance. In other words, the mere fact that a respondent enters a qualitatively inferior vocational training reflects earlier deficits in the skill endowments of the respondents.

Deficits in skill endowments indicating corresponding genetic or social dispositions in the parental home are only identified in the allocation to schools offering different forms of 
leaving certificate. Their effect is no longer significant where the choice of vocational training is concerned ${ }^{25}$, or indeed the risk of overeducation.

When controlling for work experience, firm tenure, and on-the-job training, we were able to replicate a well-known finding from the overeducation literature - that higher endowments in these skill components lower the risk of overeducation considerably. A related positive effect is found for those who acquire an additional higher vocational degree.

In sum, our results confirm the capacity of the job-competition model to explain the persistence of overeducation. This finding is in line with the conclusion drawn in Büchel (forthcoming b) that was based on a fundamentally different research design. There is no change in the relationships identified if - following Spence (1973) - the effects of individual properties are not attributed to the components of skills that have actually been accumulated, but to pure signaling effects. Particularly where school achievement measures are concerned, this possibility cannot be excluded. Irrespective of what is actually behind the effects, however, among those with a similar level of formal qualification, an above-average level of school achievement and the choice of a vocational training with good employment prospects reduce the risk of overeducation considerably. Thus, if overeducation is to be reduced, appropriate preventive measures will have to be implemented at a very early stage in the individual career, namely in the secondary school system. 


\section{References}

Becker, Gary S. 1964: Human capital. New York.

Borghans, Lex \& de Grip, Andries 2000: The Debate in Economics about Skill Utilization. In: Borghans, Lex \& Grip, Andries de (Eds.): The Overeducated Worker? The Economics of Skill Utilization. Cheltenham, UK etc., 3-26

Brückner, Erika \& Mayer, Karl Ulrich 1998: Collecting life history data. Experiences from the German Life History Study. In: Giele, Janet Z. \& Elder, Glen H. (Eds.): Methods of life course research: Qualitative and quantitative approaches. Thousand Oaks/CA, 152-181

Büchel, Felix forthcoming (a): Overqualification - Reasons, Measurement Issues, and Typological Affinity to Unemployment. In: CEDEFOP: Descy, Pascaline \& Tessaring, Manfred (Eds.): Training in Europe. Background report to the second report on vocational training research in Europe 2000. Cedefop reference document. Luxembourg

Büchel, Felix forthcoming (b): The Effects of Overeducation on Productivity in Germany - The Firms' Viewpoint. Economics of Education Review

Büchel, Felix \& Mertens, Antje 2000: Overeducation, Undereducation, and the Theory of Career Mobility. Bonn, IZA Discussion Paper No. 195

Büchel, Felix \& Neubäumer, Renate 2001: Individuelle Berufschancen als Folge branchenspezifischer Ausbildungsstrategien. Paper presented at the Annual Meeting of the Bildungsökonomischer Ausschuß des Vereins für Socialpolitik, Trier, 29-30 March 2001

Büchel, Felix \& Weißhuhn, Gernot 1998: Ausbildungsinadäquate Beschäftigung der Absolventen des Bildungssystems II. Fortsetzung der Berichterstattung zu Struktur and Entwicklung unterwertiger Beschäftigung in West- und Ostdeutschland (1993 - 1995). Report on behalf of the Federal Ministry of Education and Research. Berlin

Duncan, Greg J. and Hoffman, Saul D. 1981: The incidence and wage effects of overeducation. In: Economics of Education Review, 1 (1), 57-86

Greene, William H. 2000: Econometric Analysis. Fourth Edition. New Jersey

Groot, Wim \& Maassen van den Brink, Henriëtte 2000: Overeducation in the labor market: a metaanalysis. Economics of Education Review, 19 (2), 149-158

Hartog, Joop 2000a: On Returns to Education: Wandering along the Hills of ORU Land. In: Heijke Hans \& Muysken, Joan (Eds.), Education and Training in a Knowledge based Economy. London etc., 3-47

Hartog, Joop 2000b: Over-education and Earnings: Where are we, where should we go? Economics of Education Review, 19 (2), 131-148

Hartog, Joop \& Jonker, Nicole 1998: A Job to Match your Education: Does it Matter? In Heijke, Hans \& Borghans, Lex (Eds.): Towards a Transparent hbor Market for Educational Decisions. Aldershot UK etc., 99-118

Hartog, Joop \& Oosterbeek, Hessel 1988: Education, Allocation and Earnings in the Netherlands: Overschooling? In: Economics of Education Review, 7 (2), 185-194 
Hecker, Daniel E. 1992: Reconciling Conflicting Data on Jobs for College Graduates. In: Monthly Labor Review, 115 (7), 3-12

infas 1999: Ausbildungs- and Berufsverläufe der Geburtskohorten 1964 and 1971 in Westdeutschland. Methodenbericht zur Hauptstudie. Bonn

Leuven, Edwin, Oosterbeek, Hessel, and Ophem, Hans van 2000: Explaining International Differences in Male Wage Inequality by Differences in Demand and Supply of Skill. Unpublished Manuscript.

Muysken Joan \& ter Weel, Bas 2000: Overeducation and Crowding Out of Low-Skilled Workers. In: Borghans, Lex \& Grip, Andries de (Eds.): The Overeducated Worker? The Economics of Skill Utilization. Cheltenham, UK etc., 109-132

Neubäumer, Renate 1999: Der Ausbildungsstellenmarkt der Bundesrepublik Deutschland. Eine theoretische and empirische Analyse. Berlin

Palamidis, Helene \& Schwarze, Johannes 1989: Jugendliche beim Übergang in eine betriebliche Berufsausbildung und in die Erwerbstätigkeit. In: Mitteilungen aus der Arbeitsmarkt- und Berufsforschung, 22 (1), 114-124

Schultz, Theodore P. 1961: Education and economic growth. In: Henry, N. (Ed.): Social Factors Influencing American Education. Chicago, IL, 46-88

Sicherman, Nachum 1991: "Overeducation" in the Labor Market. In: Journal of Labor Economics, 9 (2), 101-122

Sicherman, Nachum \& Gabr, Oded 1990: A Theory of Career Mobility. In: Journal of Political Economy, 98 (1), 169-192

Sloane, Peter J., Battu, Harminder, and Seaman, Paul T. 1999: Overeducation, undereducation and the British labour market. In: Applied Economics, 31, 1437-1453

Spence, Michael 1973: Job Market Signaling. In: The Quarterly Journal of Economics, 88, 355-374

Thurow, Lester C. 1975: Generating Inequality. Mechanisms of Distribution in the U.S. Economy. New York

Thurow, Lester C. 1979: A Job-Competition Model. In: Piore, Michael J. (Ed.): Unemployment and Inflation: Institutionalist and Structuralist Views. New York, 17-32

Vella, Francis \& Gregory, R. G. 1996: Selection Bias and Human capital Investment: Estimating the Returns to Education for Young Males. In: Labour Economics, 3, 197-219

Weiss, Andrew M. 1995: Human capital vs. Signaling Explanations of Wages. In: Journal of Economic Perspectives, 9 (4), 133-154 
Table 1:

Overeducation by Various Measures of Socio-Economic Status and Skill Components

Overeducated

$(\%)$

Total

9.2

Birth cohort

$-1964$

$-1971$

7.7

\section{Gender}

- male

- female

Child(ren) $<7$ years in household (by female)

- yes

- no

8.7

Father's schooling

- low ${ }^{1}$

- intermediate or high

Nationality of parents

- both foreigners

- other

Type of school leaving certificate

- lower or no ${ }^{2}$

- lower intermediate ${ }^{3}$

- upper intermediate ${ }^{4}$

- higher ${ }^{5}$

Grade of school leaving certificate (by type)

- lower or no leaving certificate

- low or intermediate grade ${ }^{6}$

- high grade

- lower intermediate leaving certificate

- low or intermediate grade ${ }^{7}$

- high grade

- upper intermediate leaving certificate

- low or intermediate grade ${ }^{8}$

- high grade

- higher leaving certificate

- low or intermediate grade ${ }^{9} \quad 3.4$

- high grade 
Additional voc. degree (same qualification level) ${ }^{11}$

- no

- yes

Additional voc. degree (higher qualification level) ${ }^{12}$

- no

- yes

\section{Work experience}

- low ${ }^{13}$

- intermediate or high

\section{Firm tenure}

- low ${ }^{14}$

- intermediate or high

On-the-job training ${ }^{15}$

- no training measure

- one or more training measures

Significance levels: $* *=\mathrm{p}<0.01, *=\mathrm{p}<0.05,{ }^{+}=\mathrm{p}<0.10$.

Number of cases: $\mathrm{n}=1274$.

Only people with vocational degree.

Source: Own calculations from GLHS, birth cohorts 1964 and 1971, West Germany, 1998.

\section{Footnotes:}

Length of schooling in the lower quartile of the distribution: up to 10 years.

Standard lower secondary leaving certificate (einfacher Hauptschulabschluss) or no certificate at all.

"Qualified" lower secondary leaving certificate (qualifizierter Hauptschulabschluss).

Intermediate secondary leaving certificate (Realschulabschluss/mittlere Reife).

Upper secondary leaving certificate (Abitur or Fachabitur).

Grade in the lower three quartiles of the distribution: 2.6 to $6.0(1=$ best grade, $6=$ worst grade $)$.

Grade in the lower three quartiles of the distribution: 2.3 to $4.0(1=$ best grade, $4=$ worst grade).

Grade in the lower three quartiles of the distribution: 2.4 to $4.0(1=$ best grade, $4=$ worst grade $)$.

Grade in the lower three quartiles of the distribution: 2.5 to $4.0(1=$ best grade, $4=$ worst grade $)$.

Occupation-specific unemployment rate (measured in the year of training) in the upper decile of the distribution (measured separately by birth cohort).

Observation period: from the end of vocational training up until the time of the survey in 1998.

Observation period: from the end of vocational training up until the time of the survey in 1998.

In the lower quartile of the distribution: up to 5 years. Observation period: from the end of vocational training up until the time of the survey in 1998.

14 In the lowest decile of the distribution: up to 6 months. Observation period: from the end of vocational training up until the time of the survey in 1998.

15 Observation period: from the end of vocational training up until the time of the survey in 1998. 
Table 2: Determinants of Overeducation

\begin{tabular}{lll}
$\begin{array}{l}\text { Model Ia } \\
\text { (Single Equation }\end{array}$ & $\begin{array}{l}\text { Model II } \\
\text { (Multiple }\end{array}$ & $\begin{array}{l}\text { Mean } \\
\text { Probit) }\end{array}$ \\
\hline Equation Probit) &
\end{tabular}

(Constant)

1971 birth cohort (vs. 1964 cohort)

Male

Child(ren) $<7$ years in household (by female)

Father's schooling (in years)

Non-German nationality of both parents

Type of school leaving certificate

- lower or no leaving certificate

- lower intermediate leaving certificate

- upper intermediate leaving certificate

- higher leaving certificate

Grade of school leaving certificate (by type)

- Grade (by no or lower leaving certificate)

- Grade (by lower intermediate leaving certificate)

- Grade (by upper intermediate leaving certificate)

- Grade (by higher leaving certificate)

Low quality of vocational training

Additional voc. degree (same qualification level)

Additional voc. degree (higher qualification level)

Work experience (in years)

Firm tenure (greater than 6 month)

On-the-job training (number of measures)

\section{Dep.Var.: Overeducation Status (at Time of Interview)}

$\begin{array}{ll}-2.1203 * * & -2.0807 \\ (0.79) & (1.30) \\ -0.3674 * & -0.3766^{+} \\ (0.15) & (0.21) \\ -0.0363 & -0.007 \\ (0.13) & (0.43) \\ 0.2670 & 0.2662 \\ (0.19) & (0.20) \\ -0.0118 & -0.0158 \\ (0.02) & (0.05) \\ 0.1244 & 0.1363 \\ (0.25) & (0.32)\end{array}$

$\begin{array}{ll}2.9565^{* *} & 2.825^{+} \\ (0.67) & (1.53) \\ 0.9532 & 0.8199 \\ (0.90) & (1.63) \\ - & - \\ & \\ 0.9020 & 0.9033 \\ (1.31) & (1.64)\end{array}$

$-0.0718$

(0.08)

$-0.0718$

(0.09)

$0.6139 * *$

$(0.23)$

0.6156 *

(0.26)

0.7507 **

$(0.20)$

0.2820

(0.38)

0.3630 *

(0.15)

$0.7508 * *$

(0.22)

0.2808

(0.46)

0.3158

(0.96)

$-0.2420$

(0.18)

$-0.2419$

(0.19)

$-0.6296^{+}$
$(0.34)$

$-0.0388^{*}$

(0.01)

$-0.6287^{+}$

(0.36)

$-0.0387^{+}$

(0.02)

$-0.4657 * *$

(0.17)

$-0.4654 *$

(0.20)

$-0.2350 * *$

$-0.2343 * *$

(0.07)

i

0.4874

' $(0.50)$

i 0.6161

' (0.48)

' 0.2229

(0.41)

10.5320

! (2.11)

0.0376

(0.19)

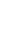

0.2394

( 0.42$)$

I 0.1569

i (0.3639)

0.4505

(0.49)

0.1530

(0.36)

i

3.1947

(1.05)

2.6200

(0.54)

2.6759

( 0.50$)$

I 2.8297

( 0.53$)$

0.1145

, (0.31)

0.1208

( 0.32$)$

0.0502

$(0.21)$

' 8.1416

' (4.2778)

0.9175

I (0.27)

1.1255

(0.06)

(cont'd in Table A1) :

Mean of dependent variable $(1=$ overeducated, $0=0.092$ correctly allocated)

Number of cases

1274

Log likelihood

(see Table A2)

Significance levels: $* * \mathrm{p}<0.01, * \mathrm{p}<0.05,^{+}<0.10$.

Only people with vocational degree.

Source: Own calculations from GLHS, birth cohorts 1964 and 1971, West Germany, 1998. 
TableA1: Determinants of Quality of Vocational Training

$\begin{array}{lll}\begin{array}{l}\text { Model Ib } \\ \text { (Single Equation }\end{array} & \begin{array}{l}\text { Model II } \\ \text { (Multiple }\end{array} & \text { Equation } \\ \text { Probit) } & \text { Probit) } & \text { (Std. Dean } \\ & & \end{array}$

\begin{tabular}{|c|c|c|c|}
\hline \multirow[b]{2}{*}{ (Constant) } & \multicolumn{3}{|c|}{$\begin{array}{c}\text { (Cont'd } \\
\text { from Table 2) } \\
\text { Dependent Variable: Quality of vocational training }\end{array}$} \\
\hline & $\begin{array}{l}-1.7553 * * \\
(0.47)\end{array}$ & $\begin{array}{l}-1.2696 \\
(0.97)\end{array}$ & $\begin{array}{l}1 \\
1 \\
1 \\
1\end{array}$ \\
\hline 1971 birth cohort (vs. 1964 cohort) & $\begin{array}{l}-0.0966 \\
(0.09)\end{array}$ & $\begin{array}{l}-0.1370 \\
(0.11)\end{array}$ & $\begin{array}{ll}0.4874 \\
(0.50) \\
\end{array}$ \\
\hline Male & $\begin{array}{l}-0.8331 * * \\
(0.10)\end{array}$ & $\begin{array}{l}-0.5907 \\
(0.44)\end{array}$ & $\begin{array}{l}0.6161 \\
(0.48)\end{array}$ \\
\hline Father's schooling (in years) & $\begin{array}{l}0.0135 \\
(0.02)\end{array}$ & $\begin{array}{l}-0.0079 \\
(0.04)\end{array}$ & $\begin{array}{ll}0.2229 \\
(0.41) \\
1\end{array}$ \\
\hline Non-German nationality of both parents & $\begin{array}{l}-0.0281 \\
(0.26)\end{array}$ & $\begin{array}{l}0.0454 \\
(0.26)\end{array}$ & $\begin{array}{l}10.5320 \\
(2.11)\end{array}$ \\
\hline Type of school leaving certificate & & & \\
\hline - no or lower leaving certificate & $\begin{array}{l}1.3232 * \\
(0.52)\end{array}$ & $\begin{array}{l}0.5518 \\
(1.30)\end{array}$ & $\begin{array}{ll}0.0376 \\
(0.19) \\
\end{array}$ \\
\hline - lower intermediate leaving certificate & $\begin{array}{l}0.4283 \\
(0.72)\end{array}$ & $\begin{array}{l}-0.2931 \\
(1.29)\end{array}$ & $\begin{array}{l}0.2394 \\
(0.42)\end{array}$ \\
\hline (- upper intermediate leaving certificate) & - & - & $\begin{array}{l}0.1569 \\
(0.3639)\end{array}$ \\
\hline - higher leaving certificate & $\begin{array}{l}0.6000 \\
(0.81)\end{array}$ & $\begin{array}{l}0.5585 \\
(0.86)\end{array}$ & $\begin{array}{ll}0.4505 \\
(0.49)\end{array}$ \\
\hline Grade of school leaving certificate (by type) & & & : \\
\hline - Grade (by no or lower leaving certificate) & $\begin{array}{l}-0.0858 \\
(0.09)\end{array}$ & $\begin{array}{l}-0.07682 \\
(0.10)\end{array}$ & $\begin{array}{l}0.1530 \\
(0.36) \\
:\end{array}$ \\
\hline - Grade (by lower intermediate leaving certificate) & $\begin{array}{l}0.2686 \\
(0.21)\end{array}$ & $\begin{array}{l}0.2604 \\
(0.24)\end{array}$ & $\begin{array}{l}3.1947 \\
(1.05)\end{array}$ \\
\hline - Grade (by upper intermediate leaving certificate) & $\begin{array}{l}0.3022 * \\
(0.14)\end{array}$ & $\begin{array}{l}0.2841^{+} \\
(0.17)\end{array}$ & $\begin{array}{l}2.6200 \\
(0.54)\end{array}$ \\
\hline - Grade (by higher leaving certificate) & $\begin{array}{l}-0.0260 \\
(0.24)\end{array}$ & $\begin{array}{l}-0.0237 \\
(0.25) \\
\text { (cont'd in Tab. A1) }\end{array}$ & $\begin{array}{l}2.6759 \\
(0.50) \\
1 \\
\end{array}$ \\
\hline $\begin{array}{l}\text { Mean of dependent variable }(1=\text { poor quality of } \\
\text { vocational training, } 0=\text { intermediate or high } \\
\text { quality of vocational training) }\end{array}$ & 0.114 & & \\
\hline Number of cases & 1274 & & \\
\hline $\begin{array}{l}\text { Log likelihood } \\
\text { Significance levels: } * * \mathrm{p}<0.01, * \mathrm{p}<0.05,{ }^{+}<0.10 \\
\text { Only people with vocational degree. } \\
\text { Source: Own calculations from GLHS, birth cohorts } 196\end{array}$ & -415.8 & (see Table A2) & \\
\hline
\end{tabular}


TableA2: Determinants of Quality of School Leaving Certificate

\begin{tabular}{|c|c|c|c|}
\hline & $\begin{array}{l}\text { Model Ic } \\
\text { (Single Equation } \\
\text { Probit) }\end{array}$ & $\begin{array}{l}\text { Model II } \\
\text { (Multiple } \\
\text { Equation Probit) }\end{array}$ & $\begin{array}{l}\text { Mean } \\
\text { (Std. Deviation) }\end{array}$ \\
\hline & Dependent Varial & $\begin{array}{l}\text { (Cont'd } \\
\text { from Table A1) } \\
\text { le: Quality of Scho }\end{array}$ & I Leaving Certificate \\
\hline (Constant) & $\begin{array}{l}0.3028 \\
(0.21)\end{array}$ & $\begin{array}{l}0.3055 \\
(0.22)\end{array}$ & \\
\hline 1971 birth cohort (vs. 1964 cohort) & $\begin{array}{l}-0.1832^{*} \\
(0.07)\end{array}$ & $\begin{array}{l}-0.1803 * \\
(0.07)\end{array}$ & $\begin{array}{l}0.4874 \\
(0.50)\end{array}$ \\
\hline Male & $\begin{array}{l}0.7469 * * \\
(0.07)\end{array}$ & $\begin{array}{l}0.7494 * * \\
(0.08)\end{array}$ & $\begin{array}{l}0.6161 \\
(0.48)\end{array}$ \\
\hline Father's schooling (in years) & $\begin{array}{l}-0.0932 * * \\
(0.01)\end{array}$ & $\begin{array}{l}-0.0942 * * \\
(0.02)\end{array}$ & $\begin{array}{l}0.2229 \\
(0.41)\end{array}$ \\
\hline Non-German nationality of both parents & $\begin{array}{l}0.3521^{+} \\
(0.19)\end{array}$ & $\begin{array}{l}0.3672^{+} \\
(0.19)\end{array}$ & $\begin{array}{l}10.5320 \\
(2.11)\end{array}$ \\
\hline $\begin{array}{l}\text { Mean of dependent variable } \\
(1=\text { no or lower intermediate school leaving } \\
\text { certificate, } 0=\text { upper intermediate or higher } \\
\text { school leaving certificate })\end{array}$ & 0.396 & & \\
\hline Number of cases & 1274 & & \\
\hline Log likelihood & -786.4 & -1532.9 & \\
\hline$\rho(1,2)$ & & $\begin{array}{l}0.0436 \\
(0.59)\end{array}$ & \\
\hline$\rho(1,3)$ & & $\begin{array}{l}0.0800 \\
(0.80)\end{array}$ & \\
\hline$\rho(2,3)$ & & $\begin{array}{l}0.4136 \\
(0.58)\end{array}$ & \\
\hline
\end{tabular}

Significance levels: $* * \mathrm{p}<0.01, * \mathrm{p}<0.05,{ }^{+}<0.10$

Only people with vocational degree.

Source: Own calculations from GLHS, birth cohorts 1964 and 1971, West Germany, 1998. 


\section{IZA Discussion Papers}

No. Author(s)

260

261

M. Lindahl

262

M. Lindahl

N. Datta Gupta

N. Smith

264

C. Dustmann

265

M. Rosholm

M. Svarer

266

C. Dustmann

O. Kirchkamp

267

A. Newell

268

A. Newell

B. Reilly

269

H. Buddelmeyer

270

B. Augurzky

C. M. Schmidt

271

B. Augurzky

C. M. Schmidt

272
C. Belzil

J. Hansen

273

The Distribution of Wages in Transition 
274 P. J. Pedersen

N. Smith

275

G. S. Epstein

T. Lecker

276

B. Amable

D. Gatti

277 R. Winter-Ebmer

278

T. M. Andersen

279

T. M. Andersen

280

P. Apps

R. Rees

281

G. Saint-Paul

282

J. Albrecht

A. Björklund

S. Vroman

283 M. Hagedorn

A. Kaul

V. Reinthaler

284 H. Rapoport

A. Weiss

285

J. Jerger

C. Pohnke

A. Spermann

286

M. Fertig

C. M. Schmidt

287 P. Guggenberger

A. Kaul

M. Kolmar
Unemployment Traps: Do Financial Dis-

incentives Matter?

Multi-Generation Model of Immigrant Earnings:

1

03/01

Theory and Application

The Impact of Product Market Competition on

5

$03 / 01$

Employment and Wages

Evaluating an Innovative Redundancy-Retraining

6

$03 / 01$

Project: The Austrian Steel Foundation

Welfare Policies, Labour Taxation and Inter-

2

$04 / 01$

national Integration

Product Market Integration, Wage Dispersion

2

$04 / 01$ and Unemployment

Household Saving and Full Consumption over

7

04/01 the Life Cycle

Information Technology and the Knowledge

5

04/01

Elites

Is There a Glass Ceiling in Sweden?

5

$04 / 01$

Welfare Analysis in a Schumpeterian Growth

7

04/01

Model with Capital

The Optimal Size for a Minority

$04 / 01$

Gut betreut in den Arbeitsmarkt?

5

$04 / 01$

Eine mikroökonometrische Evaluation der

Mannheimer Arbeitsvermittlungsagentur

First- and Second-Generation Migrants in

1

$04 / 01$

Germany -What Do We Know and What Do

People Think

Efficiency Properties of Labor Taxation in a

3

$04 / 01$ 

and the Rising Returns to Skill: US and France 1964-2000 

P. Cahuc

E. Wasmer

305

H. Bonin
H. Bonin
G. Abío
E. Berenguer
J. Gil
C. Patxot

307

G. A. Pfann

308

G. A. Pfann

D. S. Hamermesh

309

G. Brunello

310

U. Sunde 
315 W. H. J. Hassink

R. Schettkat

316 M. Frondel

C. M. Schmidt

317 R. Winkelmann

318 M. Pannenberg

G. G. Wagner

319

R. Euwals

R. Winkelmann

320

R. Fahr

U. Sunde

321

P. Telhado Pereira

P. Silva Martins

322

O. Hübler

U. Jirjahn

323

A. Frederiksen

E. K. Graversen

N. Smith

324

M. Pflüger

325

R. A. Hart

J. R. Malley

U. Woitek

326 J. S. Earle

Á. Telegdy

327

H. Gersbach

A. Schmutzler

328
On Price-Setting for Identical Products in Markets without Formal Trade Barriers

Rejecting Capital-Skill Complementarity at all

5 Costs

Health Care Reform and the Number of Doctor

Overtime Work, Overtime Compensation and the West Germany and Great Britain

Why do Firms Train? Empirical Evidence on the

First Labour Market Outcomes of Graduated Apprentices

Strategic Hiring Behavior in Empirical Matching 1

06/01 Functions

Is there a Return - Risk Link in Education?

Privatization and Productivity in Romanian Industry: Evidence from a Comprehensive Enterprise Panel in Firms

\section{Security Crisis"}


